\title{
Near-infrared Reflective Diffusion Coating Is Beneficial for Asparagus Summer Production in a Simple Plastic Greenhouse
}

\author{
Wei-Ling Chen and Chun-Jung Shen \\ Taichung District Agricultural Research and Extension Station, Tatsuen \\ Township, Changhua County, Taiwan ROC 51544
}

Additional index words. canopy temperature, covering coating, daily light integral, photosynthetic photon flux density, photosynthesis, spear yield

\begin{abstract}
Asparagus is a potential greenhouse crop, and its production is considerably affected by temperature and light, especially in the summer season. This study investigated the effects of the application of near-infrared (NIR)-reflective diffusion coating on a simple plastic greenhouse on microclimatic conditions, plant response, spear yield, and quality of the asparagus plant in central Taiwan. The results showed that NIR-reflective diffusion coating reduced the mean air temperature inside the greenhouse by 0.3 to $0.9^{\circ} \mathrm{C}$ and leaf temperature by $2.3,2.4$, and $2.4{ }^{\circ} \mathrm{C}$ at a canopy height of 50, 100, and $50 \mathrm{~cm}$, respectively. Although the accumulated daily light integral (DLI) transmitted in the coated greenhouse exhibited an $18.9 \%$ reduction compared with a $16.8 \%$ reduction in the noncoated greenhouse, a more uniform spatial light distribution was noted. Therefore, photosynthesis improved in the middle and bottom canopy, and plants could maintain a higher transpiration rate, thus resulting in atmospheric cooling. The average spear yield increased by $31.4 \%$ in summer and by $10.1 \%$ during the following harvest with a lower crude fiber (CF) content and higher $\mathrm{Ca}$ as well as $\mathrm{Mg}$ contents. In addition, the number of newly emerged shoots increased by $48.8 \%$ after the removal of the mother stalk under coating. NIR-reflective diffusion coating can be used as an energy-saving method for enhancing cooling and improving light use efficiency, thus increasing asparagus production in a greenhouse in summer.
\end{abstract}

Asparagus (Asparagus officinalis L.) is a dioecious, perennial plant belonging to the family Asparagaceae and native to Mesopotamia, East Mediterranean area. This plant is traditionally grown in temperate climates and has numerous applications. Although asparagus is predominantly a temperate crop, it is widely produced in many climatic zones (Brothwell and Brothwell, 1998). The mother stalk culture of asparagus developed in Taiwan has been commercially grown in tropical and subtropical areas since 1961 (Wang, 1970). The mother stalk is cut twice annually (usually in February and July). A total of three to eight vigorous stems per crown depending on the plant's age are selected and allowed to develop into leaf-like cladodes called fern that perform photosynthesis and accumulate photoassimilates. The spears are continuously

Received for publication 27 Sept. 2021. Accepted for publication 27 Oct. 2021.

Published online 13 January 2022.

The work was technically supported by Changhua Farmer's Association to enhance plant management and yield survey. We would also like to thank anonymous reviewers and the editor for their precious comments.

W.-L.C. is the corresponding author. E-mail: chenw1@tdais.gov.tw.

This is an open access article distributed under the CC BY-NC-ND license (https://creativecommons. org/licenses/by-nc-nd/4.0/). harvested for $\approx 8$ months (from March to June and from August to December). The aforementioned technique can prolong the plant's lifespan, improve its yield, and regulate its harvesting (Dufault, 1999; Hung, 1980). In recent years, the protected cultivation area of asparagus has been increasing mostly under simple plastic greenhouses. Asparagus can be cultivated throughout the year by integrating the mother stalk culture with greenhouse-environmental management.

In a greenhouse, solar radiation is a direct heat source that can increase temperature above the maximum tolerated level for most plants and can even reach over $50^{\circ} \mathrm{C}$ in lowlatitude countries. Temperature strongly affects asparagus growth, particularly the number and quality of spears. A temperature of 24 to $29^{\circ} \mathrm{C}$ in day and 13 to $19^{\circ} \mathrm{C}$ at night are favorable for the production and longevity of asparagus. A linear relationship was observed between the log of spear length and time at a temperature of 10 to $30^{\circ} \mathrm{C}$ for a spear length of up to $20 \mathrm{~cm}$ (Yen et al., 1996). The exponential function of spear growth was noted be faster at $33^{\circ} \mathrm{C}$ than at 28 and $36^{\circ} \mathrm{C}$ (Nichols and Woolley, 1985). In addition, accumulated photoassimilates peaked at $\approx 25^{\circ} \mathrm{C}$; when the mean temperature ranged from 15 to $20^{\circ} \mathrm{C}$, a difference of $10^{\circ} \mathrm{C}$ between the day and night temperatures promoted growth, whereas decreased growth was observed at $25^{\circ} \mathrm{C}$ (Hughes et al., 1990). Therefore, adaption to high temperature is a crucial requirement of asparagus cultivation in subtropical and tropical regions.

Many practices can regulate the temperature inside a greenhouse, including evaporation, ventilation, and liquid radiation filtering. However, these cooling systems still have some operational limitations, such as regional climatic conditions (e.g., extremely hot and humid ambient air), massive energy consumption, water quality requirement, and high costs (Abdel-Ghany et al., 2016; Giacomelli and Roberts, 1993; Nawalany et al., 2017). Passive temperature control without external energy input can be an efficient method for regulating temperature in a greenhouse. Radiative cooling at NIR radiation (700-2500 nm), which is less desirable for plant growth but can transfer heat load out of the greenhouse instead of reducing photosynthetically active radiation $(P A R, 400-700$ $\mathrm{nm})$, appears to be a more efficient method for temperature regulation (Liu et al., 2018). For this purpose, different techniques including the use of pigments for absorbance, reflection, and interference have been developed. The use of NIR-blocking or reflectioncovering painting material can be an ideal solution because of its cost-effectiveness and usability in most types of greenhouse structures (Abdel-Ghany et al., 2012; Hemming et al., 2006).

In addition to providing a cooling effect, the greenhouse cover should fulfill other requirements of crop growth including adequate $P A R$ transmission and diffusion (Al-Mahdouri et al., 2013; Hoffmann and Waaijenberg, 2002). In particular, the lower canopy leaves of vertical vein and tall stem crops are considerably shaded, resulting in the leaves receiving inadequate direct light. Different diffuse coverings or materials, such as glasses, films, sheets, and coatings, have recently become available for conventional greenhouses. Previous studies have indicated that compared with direct light, the aforementioned coverings or materials could increase the diffuseness or scattering of light, resulting in a more homogeneous light distribution, lower shading, and deeper light penetration into the crop canopy without affecting transmission ( $\mathrm{Li}$ and Yang, 2015; Liang et al., 2020). Moreover, plants cultivated under diffused light showed increased photosynthetic efficiency, lower photoinhibition, and higher biomass production (Elings et al., 2012; Holsteens et al., 2020; Li et al., 2014).

Several types of NIR-reflecting and lightdiffusing films or temporary coatings with the dual advantages of temperature cooling and light transmitting have been developed recently. These materials are easy to use and do not require external capacity input, thus saving energy (Hemming et al., 2014); however, these materials have mostly been applied in temperate regions in a glass greenhouse for the cultivation of fruit vegetables. To our knowledge, few studies have examined plant responses to environmental changes in a simple plastic greenhouse under high temperature 
conditions, especially for perennial stem vegetables. Therefore, in the present study, we performed a microclimatic survey to examine the efficiency of NIR-reflective diffusion coating in cooling and light distribution in a simple plastic greenhouse. The growth, physiology, yield, and quality of asparagus were evaluated during the summer season. The findings of this study can provide insights for developing new alternative strategies for greenhouse cultivation.

\section{Materials and Methods}

Experimental conditions and plant material. The experiment was conducted in six compartments of a simple plastic greenhouse without any active cooling equipment located in Changhua, Taiwan (lat. $23^{\circ} 55^{\prime} \mathrm{N}$, long. $\left.120^{\circ} 27^{\prime} \mathrm{E}\right)$ in 2020 . Each compartment consisted of two spans, with a north-south length of $30 \mathrm{~m}$, an east-west width of $7.2 \mathrm{~m}$, and a water gutter height of $3.5 \mathrm{~m}$. The one-slide window had a roof angle of $30^{\circ}$ and was covered with a $0.15-\mathrm{mm}$ polyethylene plastic (PEP) clear film (Plastika Kritis Group, Heraklion, Greece), resulting in $\approx 90 \%$ light transmission and $<15 \%$ haze. The three treated compartments were manually sprayed with an $13.5 \%$ infrared (IR)-reflective diffusion coating, namely ReduFuse IR (Mardenkro B.V., Baarle-Nassau, Netherlands), at $200 \mathrm{~L}$ per 0.1 ha on 31 May 2020. The film coating resulted in $\approx 12 \% P A R$ and $26 \%$ NIR net hemispherical shading and $72 \%$ haze or $37 \%$ hortiscatter in different units. After summer, the coating was removed by water brushing on 1 Sept. 2020. Conventional cultivation without roof-coating were taken as reference treatment $(\mathrm{CK})$.

Three-year-old green asparagus "Tainan No. 3" plants were tested in the experiment. The plants were grown in sandy-loam soil in a single row spaced $1 \mathrm{~m}$ apart and $20 \mathrm{~cm}$ within rows. The mother stalk culture technique was adopted. The mother stalk was first renewed on 1 Feb. 2020 and then on 24 July 2020. After cutting all aging shoots, six vigorous ferns per crown were selected and allowed to develop into mother stalks; all other emerged shoots were removed on 1 Mar. and 8 Aug. 2020. The canopy height was maintained at $\approx 150 \mathrm{~cm}$ during cultivation by using conventional techniques. Furrow irrigation and chemical fertilizers were applied when required. The crops were first harvested from 1 June 2020 to 23 July 2020, and then from 17 Aug. 2020 to 31 Oct. 2020.

Environmental conditions. Microclimatic conditions, air temperature, and photosynthetic photon flux density (PPFD), were measured using WatchDog Plant Growth Micro Stations (Spectrum Technologies Inc., Aurora, IL). Sensors were installed $200 \mathrm{~cm}$ above the ground in the middle portion of the greenhouse and $30 \mathrm{~cm}$ above the roof outside. Data were programmed to record readings at 30-minute intervals. The DLI was calculated by using PPFD (presented as $\mu \mathrm{mol} \cdot \mathrm{m}^{-2} \cdot \mathrm{s}^{-1}$ ) and then converted to solar radiation (presented as joule $\cdot \mathrm{m}^{-2} \cdot \mathrm{s}^{-1}$ ) at a conversion value of 2.1 .
Light distribution, spectrum, and canopy temperature. The transmitted light intensity and its spectral properties ranging from 350 to $800 \mathrm{~nm}$ near the plant were detected using the Spectrometer HR-550 (Hipoint Co., Kaohsiung, Taiwan) at canopy heights of 50, 100 , and $150 \mathrm{~cm}$. The ultraviolet, blue, green, red, and far-red (FR) light were distinguished and measured according to wavelengths of 350 to 400,400 to 500,500 to 600,600 to 700 , and 700 to $800 \mathrm{~nm}$, respectively. The vertical canopy temperature was detected using the IR thermal image camera R450Pro (Nippon Avionics Co., Ltd, Yokohama, Japan), and its average value was analyzed at canopy heights of 50,100 , and $150 \mathrm{~cm}$ by using TAS software (Ching Hsing Tech. Ltd., Taichung, Taiwan). The measurement was performed from 10:00 to 11:00 AM on 3 and 18 June 2020, 3 1ne 14 July 2020, and 12 and 28 Aug. 2020.

Fresh spear yield, carbohydrate, $C F$, and mineral elements. Fresh spears of commercial standard were cut every day and sampled for quality evaluation. Total soluble sugar (TSS), starch, CF, and macro-mineral content were examined once a week during both seasons and the weekly values were averaged for each season. Freeze-vacuum-dried samples were ground to fine particles and stored at $-20^{\circ} \mathrm{C}$ until further analysis. TSS and starch were extracted using the method described by Ciha and Brun (1978) and quantified using the modified phenol-sulfuric acid assay with the glucose standard curve (Dubois et al., 1956). Absorbance was measured at $490 \mathrm{~nm}$ by using a monochromator-based absorbance microplate reader UVM340 (Biochrom, Cambridge, UK). The CF content was determined using the method described by Kitcherside et al. (2000). All data are expressed as percent dry weight and are the averages of duplicate measurements.

We determined the total $\mathrm{N}$ content by using the Kjeldahl method with a Kjeltec analyzer 2300 unit (Foss Tecator AB, Hilleroed, Denmark) after preparing the digestion solution. The phosphorus $(\mathrm{P})$ content in dried powders was quantified using the phosphor-vanado-molybdate method in which the yellow color is measured in a nitric acid system by using a microplate reader at a wavelength of $470 \mathrm{~nm}$. The concentrations of mineral elements in fresh spears and emerged shoots were estimated using the method described by Hoenig and de Kersabiec (1996) with slight modifications. Furthermore, the concentrations of potassium $(\mathrm{K})$, calcium $(\mathrm{Ca})$, sodium $(\mathrm{Na})$, and magnesium $(\mathrm{Mg})$ were examined through flame atomic absorption spectrophotometry (SavantAA; GBC Scientific, Hampshire, IL) at 769, 422.6, 589, and $202.6 \mathrm{~nm}$, respectively.

Plant photosynthesis and transpiration. Photosynthesis (As) and transpiration (Tr) rates were measured on 3 and 18 June 2020 and 3 and 14 July 2020 in the summer season. Lateral fern that was present three-quarters up the main stalk at three positions (at heights of 50,100, and $150 \mathrm{~cm}$ ) was examined at 11:00 to $12: 00 \mathrm{Am}$ by using the portable photosynthesis system GSF-3000 connected to the measuring head 3010-S (Heinz Walz, Effeltrich, Germany). In the assimilation chamber, the external $\mathrm{CO}_{2}$ concentration was set to $400 \mu \mathrm{mol} \cdot \mathrm{mol}^{-1}$, and the light intensity was set according to ambient conditions. The measurements were replicated nine times at each height evenly distributed in the greenhouse.

Newly emerged shoot growth. The plant growth during the summer season was evaluated by examining the performance of newly reemerged shoots. After removing the mother stalk on $24 \mathrm{July}$, the shoot number per square meter, height, and diameter of the shoots were determined on 7 Aug. 2020. Subsequently, the contents of TSS, starch, and mineral elements in total shoots were also sampled for analysis.

Experimental design and statistical analysis. The experiments were arranged for different coating treatments in a completely randomized design with three replicates (compartments) of nine sampled plants/positions each. All statistical analyses were performed using SAS software (SAS Institute Inc., Cary, NC). The $t$ test and least-significant difference test were used to compare treatment findings when analysis of variance (ANOVA) showed a significant difference between means at $P \leq 0.05$.

\section{Results}

Greenhouse climate. Daily climate data were collected during the summer season in

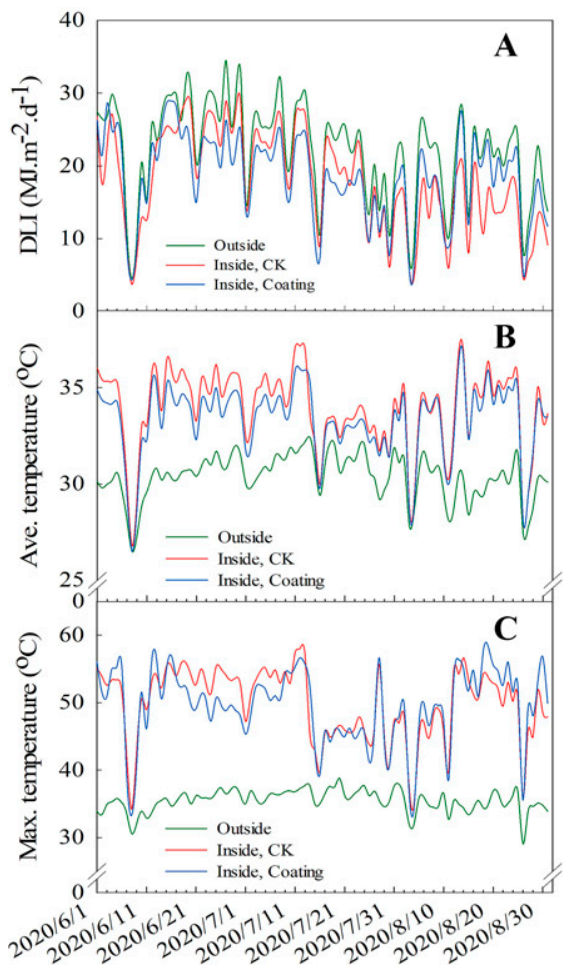

Fig. 1. Changes in daily light integral (DLI) (A), average ambient temperature (B), and maximum ambient temperature (C) in a simple plastic greenhouse during summer. CK represents uncoated treatment. 


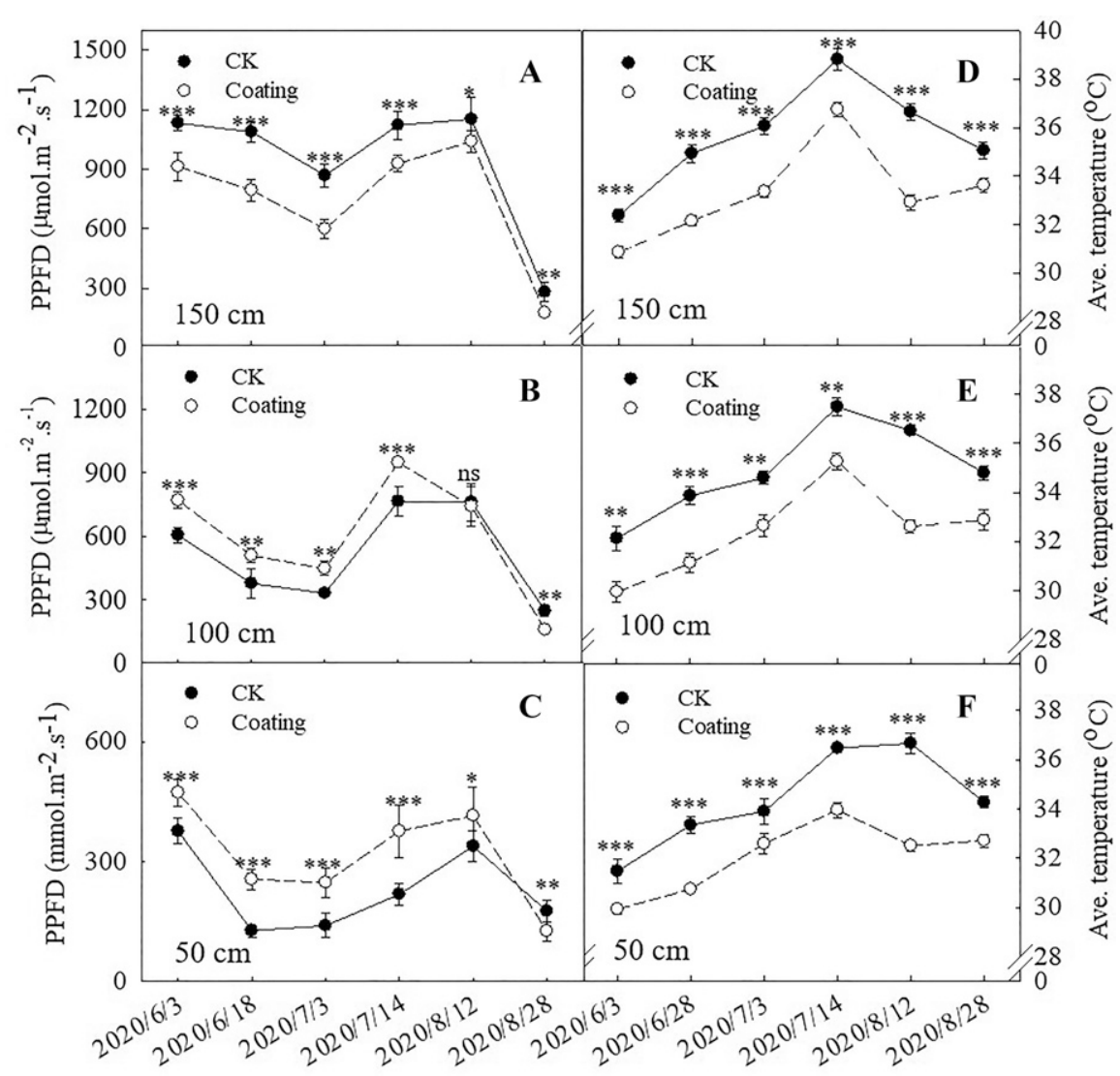

Fig. 2. Vertical changes in the photosynthetic proton flux density (PPFD) (A-C) and average canopy temperature (D-F) in a simple plastic greenhouse with near-infrared-reflective diffusion coating or not throughout the experiment. Ns, *,**,** Nonsignificant and significant at $P \leq 0.05$ and 0.01 among treatments at each measurement date examined using the $t$ test, respectively. CK represents uncoated treatment.

2020 for a total of 3 months. The fluctuating trend of DLI inside the greenhouse under both treatment conditions was identical to that observed outside the greenhouse under ambient conditions. We observed a reduction of $18.9 \%$ and $16.8 \%$ in the control and coated compartments, respectively, inside the greenhouse compared with outside the greenhouse, indicating that increased light was accumulated during the experiment. Painting with NIR-reflective diffusion coating resulted in a lower DLI in June and July. However, DLI was noted to be higher than that of the unpainted compartment since Aug. 2020 (Fig. 1A). The monthly accumulated DLI under coating was $649.9,538.1$, and 518.6 $\mathrm{MJ} \cdot \mathrm{m}^{-2}$ at reference values of $654.8,596.7$, and $410.0 \mathrm{MJ} \cdot \mathrm{m}^{-2}$ in June, July, and August, respectively.

Greenhouse temperature was significantly higher than ambient temperature. Generally, the average air temperature was 30.4 and $33.9^{\circ} \mathrm{C}$ outside and inside the greenhouse, respectively, without coating and $33.3^{\circ} \mathrm{C}$ inside the greenhouse with coating. The application of NIR-reflective diffused painting initially reduced the mean air temperature inside the greenhouse by $0.9^{\circ} \mathrm{C}$ during June but by 0.6 and $0.3{ }^{\circ} \mathrm{C}$ in July and August, respectively. The maximum temperature difference between the treatment and control conditions was similar, exhibiting decreases of $1.8,0.8$, and $1.4{ }^{\circ} \mathrm{C}$ in June, July, and August, respectively (Fig. 1B and C).

Vertical light distribution and spectral changes. Light penetration by recording the PPFD of asparagus canopy was examined. The time point between 11:00 and 12:00 AM was only considered for analysis because plants have the highest photosynthesis and the solar attitude angle ranges from $60^{\circ}$ to $70^{\circ}$ (data not shown) at this time interval. The PPFD at a height of $150 \mathrm{~cm}$ under control conditions was considerably higher than that under NIR-reflective diffused treatment at the first four dates on 3 June, 18 June, 3 July, and 14 July; by contrast, coating increased PPFD at a height of 50 and 100 $\mathrm{cm}$. After cultivation for more than 2 months, the last two measurements performed on 12 and $28 \mathrm{Aug}$. did not show a significant difference between treatments (Fig. 2A, C, and E).

The mean PPFD of the canopy throughout the 3-month cultivation period was 940.0, 511.3 , and $220.3 \mu \mathrm{mol} \cdot \mathrm{m}^{-2} \cdot \mathrm{s}^{-1}$ for the three control compartments, respectively, and $742.7,595.2$, and $315.7 \mu \mathrm{mol} \cdot \mathrm{m}^{-2} \cdot \mathrm{s}^{-1}$ for the three coated compartments, respectively, at a height of 150,100 , and $50 \mathrm{~cm}$ height, respectively. A positive linear relationship was observed between PPFD and canopy height (Fig. 3A). The slope of the line of the coating treatment was smaller than that of the control, indicating increased light penetration in the greenhouse. The point of intersection was located at a canopy height of $\approx 98.4 \mathrm{~cm}$.

Light spatial characteristics were surveyed using a spectrometer. The results showed that NIR-reflective diffusion coating reduced only solar radiation and did not change the spectral distribution at every observed height. However, the relative quantum efficiency of visible light at a wavelength of $\approx 450$ to $720 \mathrm{~nm}$ markedly decreased when the canopy height decreased to $50 \mathrm{~cm}$, particularly in the red and red edge part $(650-720 \mathrm{~nm})$ where the nearest IR light (720-800 nm) still remained at a high level under control conditions. At the same height of $50 \mathrm{~cm}$, NIR-reflective diffusion coating could maintain the higher relative intensity of visible light, and the intensity decreased only in a few parts in the IR range (Fig. 4).

Table 1 lists further specific estimated results. The intensity of light with different spectral wavelengths, including ultraviolet, blue, green, red, and FR light, which was related to plant growth, was significantly affected by canopy height. Compared with a canopy height of $150 \mathrm{~cm}$, the canopy heights of 50 and $100 \mathrm{~cm}$ showed a percent reduction of $61.5 \%$ to $69.8 \%$ and $33.1 \%$ to $39.8 \%$, respectively, for the untreated compartment depending on the light intensity at different wavelengths; the red light showed the highest reduction, whereas the FR light resulted in the lowest reduction. Coated greenhouses showed a slight reduction of $40.0 \%$ to $50.7 \%$ and $18.8 \%$ to $37.1 \%$ at a canopy height of 50 and $100 \mathrm{~cm}$, respectively. At a canopy height of 50 and $100 \mathrm{~cm}$, the blue light showed the

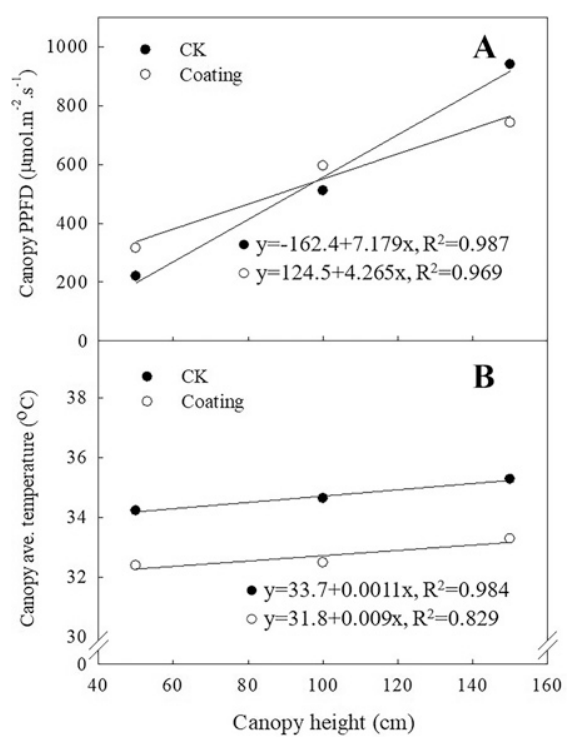

Fig. 3. Vertical canopy photosynthetic proton flux density (PPFD) (A) and temperature (B) measured at three depths in asparagus cultivated in a simple plastic greenhouse with nearinfrared-reflective diffusion coating. Data represent the means of all recording measurements on 3 and 18 June 2020, 3 and 14 July 2020, and 12 and 28 Aug. 2020. CK represents uncoated treatment. 


\section{CK}

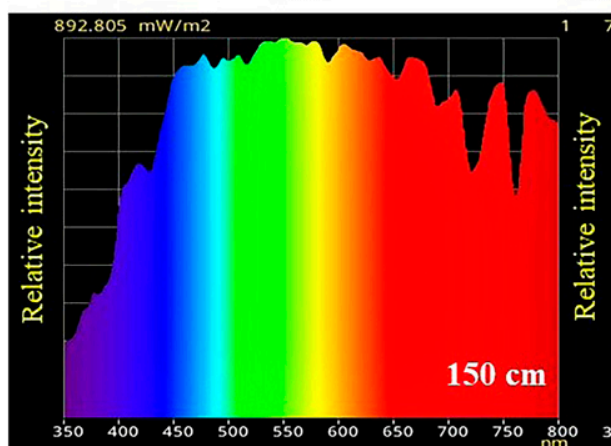

NIR-reflective diffusion coating
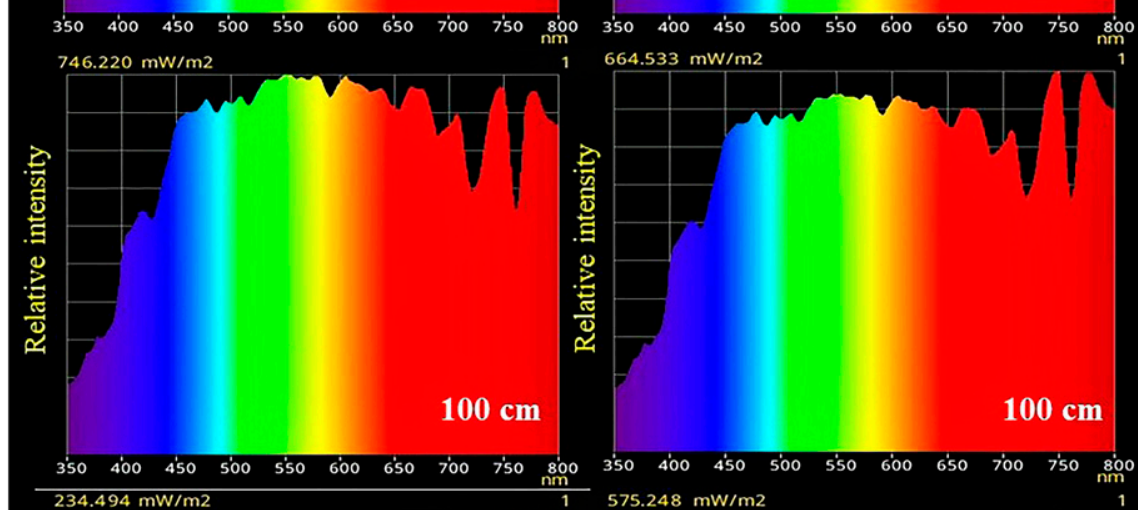

$664.533 \mathrm{~mW} / \mathrm{m} 2$
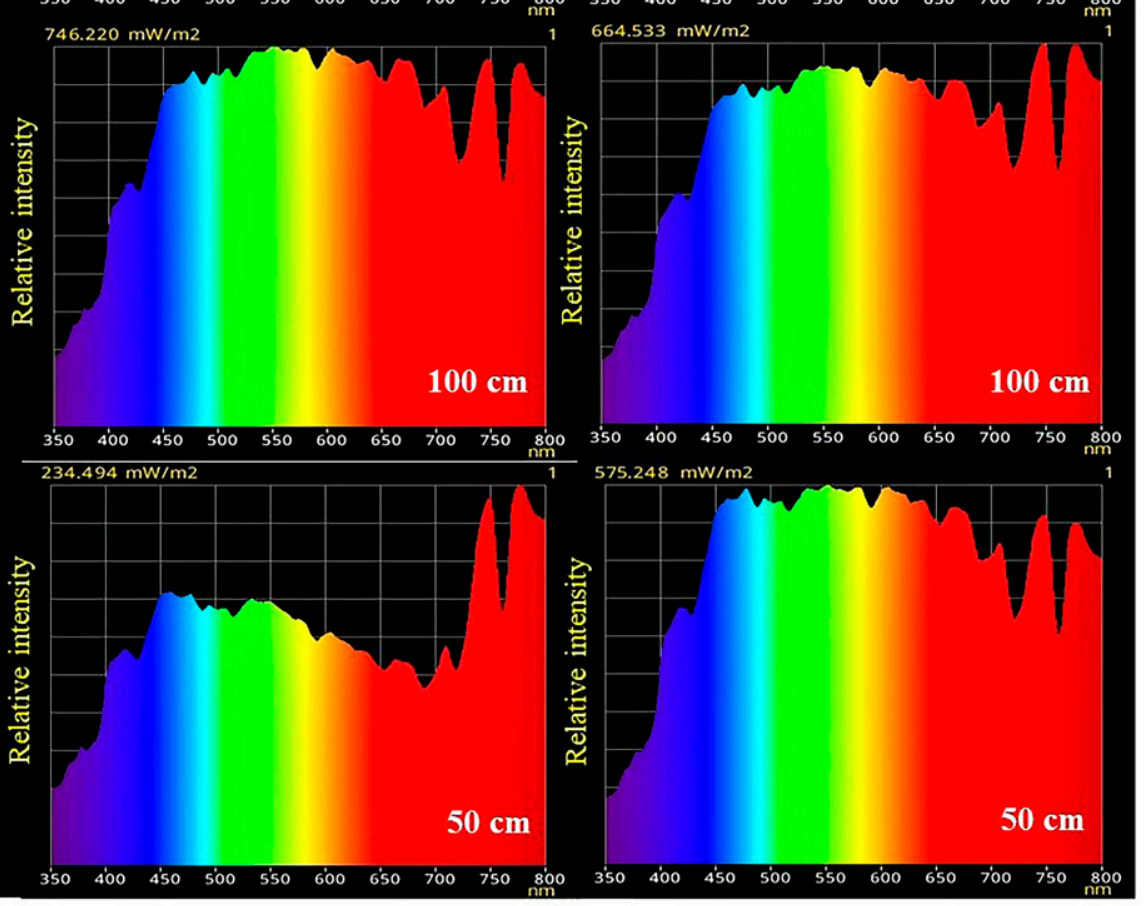

$100 \mathrm{~cm}$

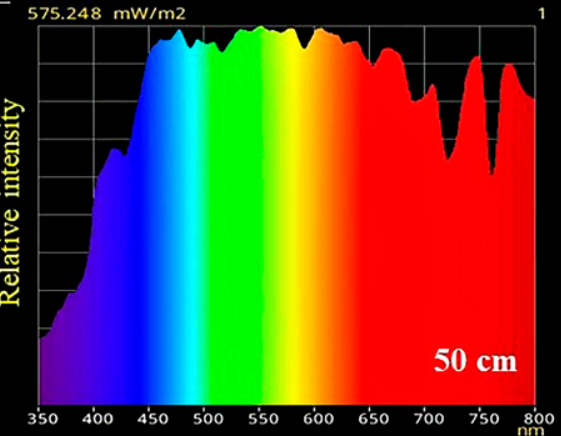

Fig. 4. Spectral distribution of light in a simple plastic greenhouse with near-infrared (NIR)-reflective diffusion coating at different heights above the ground. The measurement was obtained on 14 June 2020. CK represents uncoated treatment.

highest reduction, whereas the red and FR light showed the least reduction.

It was observed that the ratio of red light to FR light decreased with deeper light pene- tration in the control compartments; by contrast, NIR-reflecting diffusion coating resulted in a higher ratio of red light to FR light (1.28) at a lower canopy at $50 \mathrm{~cm}$, followed by a ratio

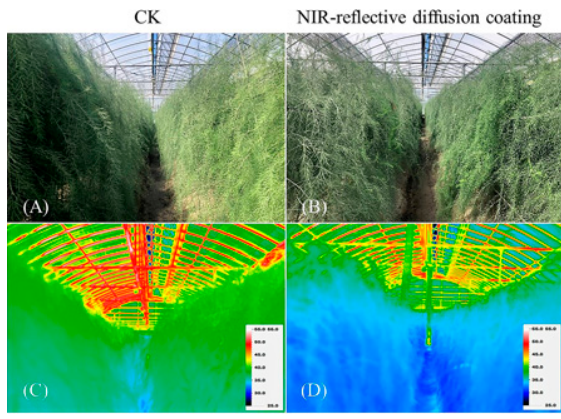

Fig. 5. Light $(\mathbf{A}, \mathbf{B})$ and temperature $(\mathbf{C}, \mathbf{D})$ distribution in a simple plastic greenhouse. Photos were taken on 14 June 2020 . CK represents uncoated treatment.

of 1.05 and 0.95 at 150 and $100 \mathrm{~cm}$, respectively (Table 1). In addition, homogeneous light penetration in the asparagus canopy under coating treatment was performed, which resulted in lower shading on the backlight side (Fig. 5A and B).

Temperature distribution. The canopy temperature was recorded while measuring PPFD. The results demonstrated that the plant temperature was unaffected by canopy height under both treatment and control conditions. Plants grown under control conditions had average canopy temperatures of 31.4 to $36.7^{\circ} \mathrm{C}, 32.1$ to $37.4^{\circ} \mathrm{C}$, and 32.4 to $38.9^{\circ} \mathrm{C}$ at a canopy height of 50,100 , and $150 \mathrm{~cm}$, respectively. However, the application of NIR-reflecting diffusion paint significantly reduced the average temperature to 29.9 to $34.0^{\circ} \mathrm{C}, \quad 29.8$ to $35.3^{\circ} \mathrm{C}$, and 30.8 to $36.7^{\circ} \mathrm{C}$ at a canopy height of 50,100 , and $150 \mathrm{~cm}$, respectively, throughout the experiment. The mean value of total of six recorded dates of the coated compartments was $2.4,2.4$, and $2.3^{\circ} \mathrm{C}$ lower than that of the untreated compartment at the upper, middle, and bottom height, respectively (Fig. 2B, D, and F). In addition, a positive linear relationship was observed between canopy temperature and height. Two regression lines showed a $1.83^{\circ} \mathrm{C}$ difference in the intercept. A considerably low slope at 0.011 (control) and 0.009 (coating) in both lines confirmed that the

Table 1. Comparison of the light intensity at different wavelengths in a simple plastic greenhouse with near-infrared-reflective diffusion coating at different heights above the ground.

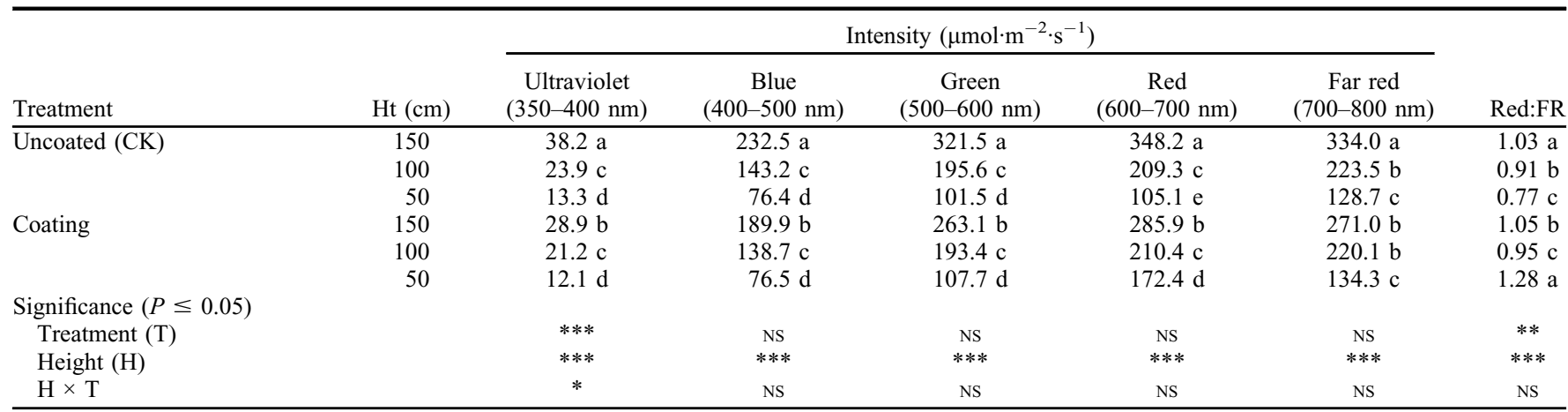

${ }^{\mathrm{z}}$ Different letters indicate significant differences between two treatments and among three heights by using the least-significant difference at $P \leq 0.05$. Data represent the means of all recording measurements performed on 3 and 18 June 2020, 3 and 14 July 2020, and 12 and 28 Aug. 2020.

NS, $* * *, * *$ Nonsignificant or significant at $P \leq 0.05,0.01$, or 0.001 , respectively. 


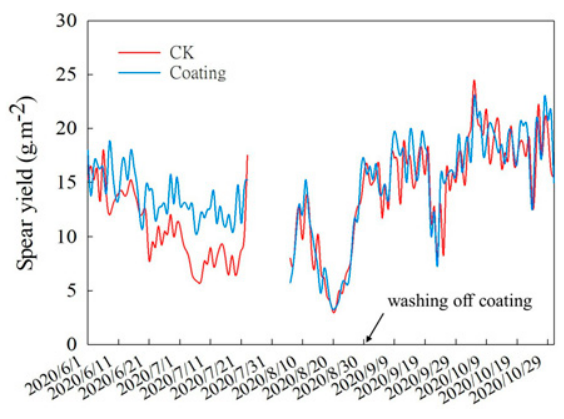

Fig. 6. Changes in the daily yield of asparagus spears cultivated in a simple plastic greenhouse with and without near-infrared-reflective diffusion coating throughout the experiment. CK represents uncoated treatment.

asparagus canopy temperature did not differ based on their height (Fig. 3B).

The findings of IR thermal imaging showed that lower temperature was observed not only in the asparagus canopy but also in the structure and roof PEP film in coated compartments compared with control compartments (Fig. 5C and D).

Yield and quality of fresh spears. Spear emergence is a crucial indictor that represents asparagus growth vigor. To ensure marketable standard, we harvested spears that were at least $18 \mathrm{~cm}$ in length by cutting them above the soil surface. The spear yield varied by seasons $(P<0.001)$. The summer harvest showed a daily decreasing trend in yield from June to the end of July, followed by an increase in yield from late August to October under both treatment and control conditions. NIR-reflecting diffusion coating increased daily spear yield during the summer season and enhanced the subsequent harvest. The total yield for the first and second harvest was higher under treatment conditions than under control conditions (first harvest: 14.4 $\mathrm{g} \cdot \mathrm{m}^{-2}$ vs. $10.8 \mathrm{~g} \cdot \mathrm{m}^{-2}$; second harvest: 15.2 $\mathrm{g} \cdot \mathrm{m}^{-2}$ and $13.8 \mathrm{~g} \cdot \mathrm{m}^{-2}$; Figs. 6 and $7 \mathrm{~A}$ ).

The quality of fresh spears was examined by measuring the concentrations of TSS, starch, $\mathrm{CF}$, and mineral elements. The results indicated that the concentration of TSS or starch was unaffected by coating treatment or harvest season. Spears harvested in June and July contained a higher CF content than did those harvested from August to October. Coating significantly reduced the CF content from $13.7 \%$ to $12.1 \%$ during the summer season; however, no difference in the CF content was examined during the second harvest (Fig. 7B-D).

A consistent result of mineral elements was displayed in both harvest periods. The concentrations of $\mathrm{N}, \mathrm{P}, \mathrm{K}$, and $\mathrm{Na}$ in fresh spears did not change under coating treatment; however, the concentrations of $\mathrm{Ca}$ and $\mathrm{Mg}$ increased significantly. In the summer harvest, the concentrations of $\mathrm{Ca}$ and $\mathrm{Mg}$ in spears under coating treatment increased from $696.9 \mathrm{mg} \cdot \mathrm{kg}^{-1}$ and $408.5 \mathrm{mg} \cdot \mathrm{kg}^{-1}$ to $1132.9 \mathrm{mg} \cdot \mathrm{kg}^{-1}$ and $794.5 \mathrm{mg} \cdot \mathrm{kg}^{-1}$, demonstrating an increase of 1.63 and 1.94 times, respectively. In addition, during the second harvest, these two elements exhibited slight increases of 1.17 and 1.11 times, respectively, after the removal of coating (Table 2).

Plant photosynthesis-related physiology. The effect of coating treatment on asparagus growth was determined by examining As and $\mathrm{Tr}$ in the branches of leaf-like cladodes at different canopy heights. The As decreased from the top to bottom in both treatments. However, no difference in the top canopy layer was observed between treatments $(P>$ 0.01 ). The As was noted to be significantly higher at a canopy height of $100 \mathrm{~cm}$ in

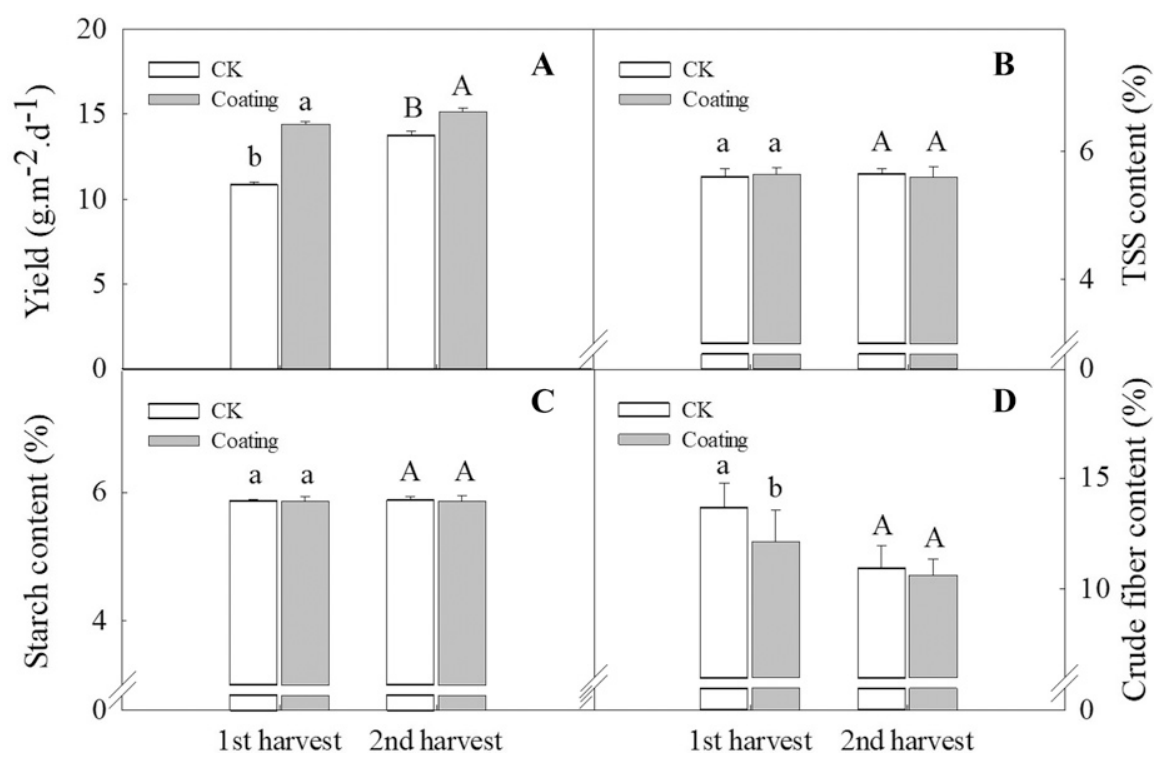

Fig. 7. Comparison of daily fresh spear yield (A), total soluble sugar (TSS) (B), starch (C), and crude fiber content (D) of asparagus cultivated in a near-infrared-reflective diffusion-coated greenhouse and control in two harvesting seasons. Different lowercase and upper letters indicate significant differences between treatments in the first and second harvest as examined through $t$ test at $P \leq 0.05$, respectively. CK represents uncoated treatment. coating treatment compared with control conditions $(P=0.003-0.015)$ with a difference of $\approx 1.29-1.82 \mu \mathrm{mol} \mathrm{CO} \mathrm{CO}_{2} \cdot \mathrm{m}^{-2} \cdot \mathrm{s}^{-1}$. Similar results were observed at a canopy height of $50 \mathrm{~cm}$; however, only partial measuring dates showed a significant variation $(P=$ 0.004-0.308; Fig. 8A-C).

Coating treatment and canopy height significantly affected the Tr; however, no interaction between these factors was observed among the four measurements $(P=$ $0.329-0.938)$. The plants showed the highest Tr level at a canopy height of $150 \mathrm{~cm}$, followed by those at 100 and $50 \mathrm{~cm}$. Asparagus grown in a coated greenhouse had a higher Tr than that grown in a noncoated greenhouse. In particular, on 3 June 2020, a marked difference between treatments was observed for all three canopy heights $(P=$ $0.001,0.007$, and 0.032 , respectively); compared with control conditions, NIR-reflective diffusion coating resulted in an increase of $4.54,2.95$, and $2.60 \mathrm{mmol}^{-2} \cdot \mathrm{s}^{-1}$ in the $\mathrm{Tr}$ under coating treatment (Fig. 8D-F). Furthermore, no difference in As and $\mathrm{Tr}$ was observed between both treatments after the removal of coating (data not shown).

New shoot growth. Newly emerged shoots were sampled after excising previous mother stocks for 2 weeks. Plants cultivated under NIR-reflective diffusion coating had more shoots; however, no difference in shoot height and diameter was observed between treatment and control conditions. The number of newly emerged shoots per square meter was 12.2 and 8.2 under coating and control conditions, respectively. The TSS content was higher in plants cultivated in a coated greenhouse $(5.8 \%)$ than in a noncoated greenhouse $(5.4 \%)$; the same findings were observed for the starch content (Table 3 ). The contents of macro-mineral elements in new shoots were similar to those in fresh spears. Although coating maintained the contents of $\mathrm{K}, \mathrm{P}$, and $\mathrm{Na}$, it increased those of $\mathrm{Ca}$ and $\mathrm{Mg}$. The $\mathrm{Ca}$ and $\mathrm{Mg}$ contents in shoots increased from 539.0 to $931.3 \mathrm{mg} \cdot \mathrm{g}^{-1}$ and from 454.7 to $1087.5 \mathrm{mg} \cdot \mathrm{kg}^{-1}$, exhibiting an increase of 1.72 and 2.39 times, respectively (Table 4).

\section{Discussion}

The use of the mother stalk culture system can prolong the lifespan of the asparagus plant, improve its spear quality, and regulate its production throughout the year, particularly in a greenhouse facility (Dufault, 1991; Lin and Huang, 1978). The spears are first harvested from March to June and then from August to December in Taiwan. The renewal of the mother stalk is performed between the two harvests (Hung, 1980). Thus, spear production and new shoot development usually occur during the summer season. In particular, from June to August, when the average and maximum ambient temperatures during these hottest months were 28.7 and $35.7^{\circ} \mathrm{C}$, respectively, for the past 3 years in central Taiwan where the major asparagus production located (Taiwan Central Weather 
Table 2. Comparison of the contents of mineral elements in the fresh spears of asparagus cultivated under near-infrared-reflective diffusion coating treatment and control conditions in the two harvesting seasons.

\begin{tabular}{|c|c|c|c|c|c|c|}
\hline Treatment & $\mathrm{N}(\%)$ & $\mathrm{P}\left(\mathrm{mg} \cdot \mathrm{kg}^{-1}\right)$ & $\mathrm{K}\left(\mathrm{mg} \cdot \mathrm{kg}^{-1}\right)$ & $\mathrm{Na}\left(\mathrm{mg} \cdot \mathrm{kg}^{-1}\right)$ & $\mathrm{Ca}\left(\mathrm{mg} \cdot \mathrm{kg}^{-1}\right)$ & $\mathrm{Mg}\left(\mathrm{mg} \cdot \mathrm{kg}^{-1}\right)$ \\
\hline & \multicolumn{6}{|c|}{ First harvest } \\
\hline Uncoated (CK) & 3.9 & 23.4 & 694.3 & 285.1 & 696.9 & 408.5 \\
\hline Coating & 4.1 & 23.1 & 635.7 & 282.4 & 1132.9 & 794.5 \\
\hline \multirow[t]{2}{*}{$t$ test } & NS & NS & NS & NS & $* * *$ & $* * *$ \\
\hline & \multicolumn{6}{|c|}{ Second harvest } \\
\hline Uncoated (CK) & 4.7 & 28.9 & 589.2 & 257.3 & 1260.2 & 1335.7 \\
\hline Coating & 4.6 & 27.8 & 651.7 & 279.1 & 1471.9 & 1478.2 \\
\hline$t$ test & NS & NS & NS & NS & $* *$ & $*$ \\
\hline \multicolumn{7}{|l|}{ Significance $(P \leq 0.05)$} \\
\hline Harvest season (Hs) & $* * *$ & $* * *$ & NS & NS & $* * *$ & $* * *$ \\
\hline Treatment $(\mathrm{T})$ & NS & NS & NS & NS & $* * *$ & $* *$ \\
\hline $\mathrm{Hs} \times \mathrm{T}$ & NS & NS & NS & NS & $* * *$ & $* * *$ \\
\hline
\end{tabular}

NS, $* * *, * * *$ Nonsignificant or significant at $P \leq 0.05,0.01$, or 0.001 , respectively.

Bureau, 2021). Moreover, increases of 3.5 and $14.4{ }^{\circ} \mathrm{C}$ were recorded in the average and maximum ambient temperatures, respectively, inside the plastic greenhouse during this study (Fig. 1). High temperatures considerably restrict cultivation in a simple greenhouse without a cooling system.

Heat stress exerted various harmful effects on plant anatomy, physiology, and biochemistry, thus causing a decrease in plant yield. Photosynthesis-related molecules are primary effected targets (Hall, 2001; Wahid et al., 2007). Ribulose-1,5-bisphosphate carboxylase/oxygenase (Rubisco) and the ATP generation system involving carbon fixation as well as the oxygen-evolving complex along with associated cofactors in photosystem II were damaged due to the overproduction of reactive oxygen species. Nonstomatal limitations were responsible for the reduction in photosynthesis caused by decreased carbon fixation and oxygen evolution, as well as electron transduction disruption (Allakhverdiev et al., 2008; Khanal et al., 2017; Sarvajeet and Narendra, 2010). Furthermore, physiological responses to stomatal limitations can reduce photosynthesis under high temperatures in crops such as radish, tall fescue, and asparagus (Chen et al., 2014; Cui et al., 2006; Yue et al., 1992).

High temperature considerably affected asparagus growth. With an increase in

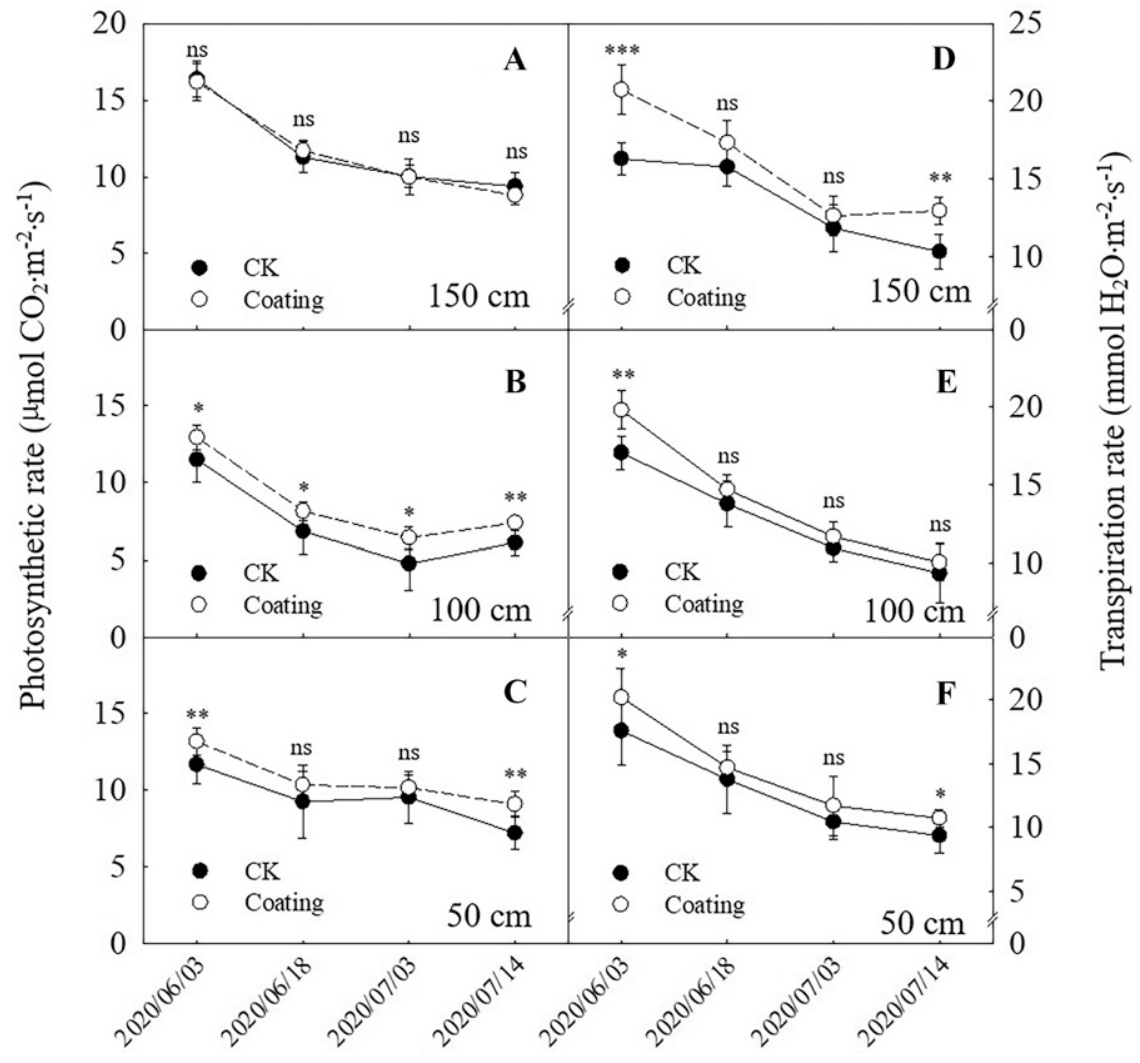

Fig. 8. Photosynthetic rate and transpiration rate of shoots at canopy heights of 150 (A, D), 100 (B, E), and $50 \mathrm{~cm}(\mathbf{C}, \mathbf{F})$ of asparagus shoots cultivated under near-infrared-reflective diffusion coating and control conditions. NS, *, *,* Nonsignificant and significant at $P \leq 0.05,0.01$, and 0.001 level among treatments on each measuring date, as determined through $t$ test, respectively. CK represents uncoated treatment. temperature from $20 / 20^{\circ} \mathrm{C}$ to $35 / 15^{\circ} \mathrm{C}$, the mature fern exhibited a significant increase in stomatal limitations and a significant decrease in carboxylation efficiency. Furthermore, the photorespiration rate of the fern's crown tended to increase when day temperature increased from 20 to $40^{\circ} \mathrm{C}$; however, the net photosynthesis rate declined (Woolley et al., 1996). The harvest season significantly affected the yield and quality of spears $(P<$ 0.05 , ANOVA). Compared with the second harvest, the first harvest showed a lower daily yield, higher $\mathrm{CF}$ content, and lower mineral element content (e.g., $\mathrm{N}, \mathrm{P}, \mathrm{Ca}$, and $\mathrm{Mg}$ ); however, ambient temperature outside the greenhouse was $2.6^{\circ} \mathrm{C}$ higher during the first harvest than during the second harvest (Fig. 7; Table 2).

A high crop yield is determined based on the production and efficiency of photoassimilates in the harvested organ (Daie, 1985). Photosynthesis promotes biomass production and is affected by $P A R$. Solar radiation results in $\approx 1 \%$ additional production for each $1 \%$ additional light penetrating inside a greenhouse (Kläring and Krumbein, 2013; Lawlor, 1995; Marcelis et al., 2006). Photosynthesis and carbohydrate levels in the asparagus plant are directly related to their growth vigor and yield (Shelton and Lacy, 1980). Some studies have reported a link between fern photosynthesis and annual spear yield and suggested that the light-saturated photosynthesis rate $\left(\mathrm{A}_{\mathrm{sat}}\right)$ can predict the yield of asparagus (Benson and Takatori,1980; Faville et al., 1999; Woolley et al., 1996). Therefore, adjusting the optimal temperature and improving light use efficiency (LUE) can be beneficial for asparagus cultivation in a greenhouse.

A study reported that $95 \%$ of the $P A R$ waveband is absorbed by plants for photosynthesis; however, $\approx 50 \%$ of NIR is reflected and then absorbed by the material covering a greenhouse, resulting in heat accumulation (Kempkes and Hemming, 2012). Our study results indicated that applying NIR-reflective diffusion coating in summer exerted a positive cooling effect, thus reducing the ambient temperature in a plastic-film greenhouse, particularly when indoor temperature was more than $35^{\circ} \mathrm{C}$ (Fig. 1). The temperature of greenhouse construction and plants was also reduced significantly (Figs. 2 and 5). The average ambient 
Table 3. Plant growth and carbohydrate content of the newly emerged shoots of asparagus cultivated under near-infrared-reflective diffusion coating and control conditions after removing the mother stalk for 2 weeks.

\begin{tabular}{lccccc}
\hline Treatment & Shoot number & Shoot ht $(\mathrm{cm})$ & Shoot diam $(\mathrm{mm})$ & TSS $(\%)$ & Starch $(\%)$ \\
\hline Uncoated $(\mathrm{CK})$ & 8.2 & 132.2 & 11.2 & 5.4 & 5.8 \\
Coating & 12.2 & 127.4 & 11.4 & 5.8 & 5.9 \\
$t$ test & $* * *$ & NS & NS & $* *$ & NS \\
\hline
\end{tabular}

TSS $=$ total soluble sugar.

NS, **, ***Nonsignificant or significant at $P \leq 0.01$ or 0.001 , respectively.

temperature under treatment conditions was lower by 0.9 to $0.3^{\circ} \mathrm{C}$ than that under control conditions from June to August, and a decrease of 1.5 to $4.2^{\circ} \mathrm{C}$ in canopy temperature was observed depending on the date at which the temperature was recorded and the canopy height. This finding is in line with those reported by Garcia-Alonso et al. (2006), Hemming et al. (2006), Li et al. (2014), and Mutwiwa et al. (2017); however, the cooling effectiveness of coating was affected by its durability, coating type, and environmental conditions. No difference in cooling efficiency was observed between treatment and control conditions since August, indicating that the cooing efficiency of the coating was sustained only for 2 months during wet weather in the summer season of Taiwan or that the advantage of NIR reflection was more prominent when the temperature was relatively high.

Although the light intensity of ultraviolet, $P A R$, and NIR light (700-800 $\mathrm{nm})$ was affected mainly by canopy height according to spectral comparison results illustrated in Table 1, coating still reduced the light intensity at a canopy height of $150 \mathrm{~cm}$. Meanwhile, the lower intensity of NIR can be attributed to the reflection of coating (Fig. 4). NIR-reflective coating reduced radiative heat penetrating in the greenhouse through either light shading or by exerting a cooling effect. In addition, transpiration in which evaporation occurs inside the stomata can be another contributor to the cooling effect and be used for greenhouse climate control (Georgios et al., 2019; Gonzalez-Real and Baille, 2006; Stanghellini, 1987). Under solar energy, water generated from the plant's surface through transpiration is converted into water vapor through the absorption of latent heat. Furthermore, when atmospheric humidity increases and plant temperature decreases, the greenhouse absorbs heat from the surrounding environment, leading to a reduction in ambient temperature and thus the maintenance of equilibrium (Gupta et al., 2018; Seginer, 1994). Asparagus plants cultivated in a coated greenhouse had a higher transpiration rate, indicating that the plants received an adequate amount of water and had less stomatal limitations (Fig. 8). This physiological response is not only beneficial for temperature adjustment but also improves nutrient uptake and transportation, resulting in higher $\mathrm{Ca}$ and $\mathrm{Mg}$ contents in the fresh spears and newly emerged shoots (Tables 2 and 4).

Greenhouse cultivators aim to improve LUE and accelerate photosynthesis for increasing plant yield. Although DLI slightly decreased by $\approx 2.7 \%$ in the greenhouse with NIR-reflective diffusion coating, the daily level still required for asparagus is equal to or lower than $17 \mathrm{~mol} \cdot \mathrm{m}^{-2} \cdot \mathrm{d}^{-1}$ (Fig. 1) (Cossu et al., 2020). NIR-reflective diffusion coating increased the uniformity of the horizontal or vertical distribution of light. A higher PPFD observed at a canopy height of 50 and $100 \mathrm{~cm}$ showed better light penetration in the middle and bottom of the plant (Figs. 2 and 8). During the summer harvest, the average daily yield was $3.4 \mathrm{~g} \cdot \mathrm{m}^{-2}$ higher $(+31.4 \%)$ than control. During the second harvest, the average daily yield was higher by $1.4 \mathrm{~g} \cdot \mathrm{m}^{-2}(+10.1 \%)$ even when the coating was removed (Fig. 7). In addition, undesirable photoinhibition caused by increased light intensity in the upper canopy that exerts a negative effect on Tr could be overcome through diffused lighting (Fig. 8). Previous studies have indicated that vigorous fern growth exerted a positive effect on spear yield in the following harvest (Faville et al., 1999; Moon, 1976; Wolyn,1993). Thus, the growth of asparagus can be promoted through the summer months by applying coating treatment, which could result in the accumulation of increased carbohydrates predominantly in the fleshy storage root or crown underground as a source for the next harvest.

The efficiency of diffused light is dependent on plant morphology, shoot or leaf orientation, cropping season, planting density, even greenhouse location, design, construction, and covering material ( $\mathrm{Li}$ and Yang, 2015; Sarlikioti et al., 2011). Therefore, the asparagus management model can be modified for promoting the diffused effect. Moreover, diffused light can be more beneficial for crop biomass production compared with direct light over $\approx 750 \mathrm{mmol} \cdot \mathrm{m}^{-2} \cdot \mathrm{s}^{-1}($ Earles et al., 2017; Holsteens et al., 2020).

Table 4. The contents of mineral elements in the newly emerged shoots of asparagus cultivated under near-infrared-reflective diffusing coating and control conditions after removing the mother stalk for 2 weeks.

\begin{tabular}{lcccccc}
\hline Treatment & $\mathrm{N}(\%)$ & $\mathrm{P}\left(\mathrm{mg} \cdot \mathrm{kg}^{-1}\right)$ & $\mathrm{K}\left(\mathrm{mg} \cdot \mathrm{kg}^{-1}\right)$ & $\mathrm{Na}\left(\mathrm{mg} \cdot \mathrm{kg}^{-1}\right)$ & $\mathrm{Ca}\left(\mathrm{mg} \cdot \mathrm{kg}^{-1}\right)$ & $\mathrm{Mg}_{\left(\mathrm{mg} \cdot \mathrm{kg}^{-1}\right)}$ \\
\hline Uncoated $(\mathrm{CK})$ & 3.8 & 24.0 & 449.8 & 238.7 & 539.0 & 454.7 \\
Coating & 3.5 & 25.4 & 458.2 & 286.8 & 931.3 & 1087.5 \\
$t$ test $(P<0.05)$ & $\mathrm{NS}^{\mathrm{z}}$ & $\mathrm{NS}$ & $\mathrm{NS}$ & $\mathrm{NS}$ & $* *$ & $* * *$
\end{tabular}

NS, **,***Nonsignificant or significant at $P \leq 0.01$ or 0.001 , respectively.
Coating should be applied during the summer months to improve LUE.

In summary, our study results revealed that NIR-reflective diffusion coating improved microclimatic conditions in a greenhouse by reducing temperature and homogeneous spatial light distribution during the summer season. Optimal temperature and favorable LUE can increase photosynthesis and transpiration in asparagus plants, thus increasing its yield and quality. Unfortunately, we could not identify whether NIR reflection or diffusion contributed to these beneficial effects based on our study findings.

The individual function as well as integrated effect and many perspectives of coating application are worthy for further study.

\section{Literature Cited}

Abdel-Ghany, A., I. Al-Helal, P. Picuno, and M. Shady. 2016. Modified plastic net-houses as alternative agricultural structures for saving energy and water in hot and sunny regions. Renew. Energy 93:332-339, https://doi.org/ 10.1016/j.renene.2016.02.084.

Abdel-Ghany, A.M., I.M. Al-Helal, S.M. Alzarhani, A.A. Alsadon, I.M. Ali, and R.M. Elleithy. 2012. Covering materials incorporating radiation-preventing techniques to meet greenhouse cooling challenges in arid regions: A review. ScientificWorldJournal 2012(1-2):90630, https:// doi.org/10.1100/2012/906360.

Allakhverdiev, S.I., V.D. Kreslavski, V.V. Klimov, A. Dmitry, C. Robert, and M. Prasanna. 2008. Heat stress: An overview of molecular responses in photosynthesis. Photosynth. Res. 98(1-3):541-550, https://doi.org/10.1007/S11120008-9331-0.

Al-Mahdouri, A., M. Baneshi, H. Gonome, J. Okajima, and S. Maruyama. 2013. Evaluation of optical properties and thermal performances of different greenhouse covering materials. Sol. Energy 96:21-32, https://doi.org/10.1016/ j.solener.2013.06.029.

Benson, B.L. and F.H. Takatori. 1980. Partitioning of dry matter in open-pollinated and $F_{1}$ hybrid cultivars of asparagus. J. Amer. Soc. Hort. Sci. 105:567-570.

Brothwell, D. and P. Brothwell. 1998. Food in antiquity: A survey of the diet of early people. John Hopkins University Press, Baltimore, MD.

Chen, W.L., W.J. Yang, H.F. Lo, and D.M. Yeh. 2014. Physiology, anatomy, and cell membrane thermostability selection of leafy radish (Raphanus sativus var. oleiformis Pers.) with different tolerance under heat stress. Scientia Hort. 179:367-375, https://doi.org/10.1016/j. scienta.2014.10.003.

Ciha, A.J. and W.A. Brun. 1978. Effect of pod removal on nonstructural carbohydrate concentration in soybean tissue. Crop Sci. 18:773-776, https://doi.org/10.2135/cropsci1978.0011183X0 01800050020x.

Cossu, M., A. Yano, S. Solinas, P.A. Deligios, M.T. Tiloca, A. Cossu, and L. Ledda. 2020. Agricultural sustainability estimation of the European photovoltaic greenhouses. Eur. J. Agron. 118:1260-1274, https://doi.org/10.1016/ j.eja.2020.126074

Cui, L., J. Li, Y. Fan, S. Xu, and Z. Zhang. 2006. High temperature effects on photo-synthesis, PSII functionality and antioxidant activity of two Festuca arundinacea cultivars with 
different heat susceptibility. Bot. Stud. (Taipei, Taiwan) 47:61-69.

Daie, J. 1985. Carbohydrate partitioning and metabolism in crops. Hort. Rev. (Amer. Soc. Hort. Sci.) 7:69-108, https://doi.org/10.1002/ 9781118060735.ch2.

Dubois, M., K. Gilles, J. Hamilton, P. Rebers, and F. Smith. 1956. Colorimetric method for determination of sugars and related substances. Anal. Chem. 28(3):350-356, https://doi.org/ 10.1021/ac60111a017.

Dufault, R.J. 1999. Mother stalk culture does not improve plant survival or yield of spring and summer-forced asparagus in South Carolina. HortScience 34(2):225-228, https://doi.org/10. 21273/HORTSCI.34.2.225.

Earles, J., G. Théroux-Rancourt, M. Gilbert, A. McElrone, and C. Brodersen. 2017. Excess diffuse light absorption in upper mesophyll limits $\mathrm{CO}_{2}$ drawdown and depresses photosynthesis. Plant Physiol. 174:1082-1096, https://doi.org/ 10.1104/pp.17.00223.

Elings, A., T. Dueck, E. Meinen, and F. Kempkes. 2012. Analysis of the effects of diffuse light on photosynthesis and crop production. Acta Hort. 957:45-52, https://doi.org/10.17660/ActaHortic. 2012.957.4.

Faville, M.J., W.B. Silvester, T.G.A. Green, and W.A. Jermyn. 1999. Photosynthetic characteristics of three asparagus cultivars differing in yield. Crop Sci. 39:1070-1077, https://doi.org/ 10.2135/cropsci1999.0011183X003900040019x.

Garcia-Alonso, Y., E. Espi, A. Salmeron, A. Fontecha, A. Gonzalez, and J. Lopez. 2006. New cool plastic films for greenhouse covering in tropical and subtropical areas. Acta Hort. 719:131-137, https://doi.org/10.17660/ActaHor tic.2006.719.12.

Georgios, N., N. Damianos, K. Nikolaos, and K. Constantinos. 2019. Effects of cooling systems on greenhouse microclimate and cucumber growth under mediterranean climatic conditions. Agronomy (Basel) 9(6):300-315, https:// doi.org/10.3390/agronomy9060300.

Giacomelli, G.A. and W.J. Roberts. 1993. Greenhouse covering systems. HortTechnology 3:50-58, https://doi.org/10.21273/HORTTECH. 3.1.50.

Gonzalez-Real, M.M. and A. Baille. 2006. Plant response to greenhouse cooling. Acta Hort. 719:427-438, https://doi.org/10.17660/ActaHortic. 2006.719 .48

Gupta, S.K., J. Ram, and H. Singh. 2018. Comparative study of transpiration in cooling effect of tree species in the atmosphere. J. Geosci. Environ. Prot. 6:151-166, https://doi.org/10.4236/ gep.2018.68011.

Hall, A.E. 2001. Crop response to environment. CRC Press, LLC, Boca Raton, FL. https://doi. org/10.1201/9781420041088.

Hemming, S., F. Kempkes, N. van der Braak, T. Dueck, and N. Marissen. 2006. Greenhouse cooling by NIR-refection. Acta Hort. 719:97-106, https://doi.org/10.17660/ActaHortic.2006.719.8.

Hemming, S., V. Mohammadkhani, and J. van Ruijven. 2014. Material technology of diffuse greenhouse covering materials-influence on light transmission, lights scattering, and light spectrum. Acta Hort. 1037:883-895, https://dx. doi.org/10.17660/ActaHortic.2014.1037.118.

Hughes, A.R., M.A. Nichols, and D.J. Woolley. 1990. The effect of temperature on the growth of asparagus seedlings. Acta Hort.
271:451-456, https://doi.org/10.17660/Acta Hortic. 1990.271.63.

Hung, L. 1980. Special aspect of asparagus growing in Taiwan. J. Chinese Soc. Hort. Sci. 26(1):1-10, https://doi.org/10.6964\%2fJCSHS.198001.0001.

Hoenig, M. and A.M. de Kersabiec. 1996. Sample preparation steps for analysis by atomic absorption spectroscopy methods: Present status. Spectrochim. Acta Part B At Spectrosc. 51:1297-1307, https://doi.org/10.1016/0584-8547 (96)01507-8.

Hoffmann, S. and D. Waaijenberg. 2002. Tropical and subtropical greenhouses - A challenge for new plastic films. Acta Hort. 578:163-169, https://doi.org/10.17660/ACTAHORTIC.2002. 578.19 .

Holsteens, K., R. Moerkens, B. van de Poel, and W. Vanlommel. 2020. The effect of low-haze diffuse glass on greenhouse tomato and bell pepper production and light distribution properties. Plants 9(7):806-821, https://doi.org/10.3390/ plants9070806.

Kempkes, F.L.K. and S. Hemming. 2012. Calculation of NIR effect on greenhouse climate in various conditions. Acta Hort. 927:543-550, https://doi.org/10.17660/ActaHortic.2012.927.66.

Khanal, N., G.E. Bray, A. Grisnich, B.A. Moffatt, and G.R. Gray. 2017. Differential mechanisms of photosynthetic acclimation to light and low temperature in Arabidopsis and the extremophile Eutrema salsugineum. Plants 6:32-60, https://doi.org/10.3390/plants6030032.

Kitcherside, M.A., E.F. Glen, and A.J.F. Webster. 2000. FibreCap: An improved method for the rapid analysis of fiber in feeding stuffs. Anim. Feed Sci. Technol. 86:125-132, https://doi.org/ 10.1016/S0377-8401\%2800\%2900153-X.

Kläring, H.P. and A. Krumbein. 2013. The effect of constraining the intensity of solar radiation on the photosynthesis, growth, yield, and product quality of tomato. J. Agron. Crop Sci. 199(5): 351-359, https://doi.org/10.1111/jac.12018.

Lawlor, D.W. 1995. Photosynthesis, productivity, and environment. J. Expt. Bot. 46:1449-1461, https://doi.org/10.1093/jxb/46.special_issue.1449.

Li, T., E. Heuvelink, F. van Noort, J. Kromdijk, and L.F.M. Marcelis. 2014. Responses of two Anthurium cultivars to high daily integrals of diffuse light. Scientia Hort. 179:306-313, https://doi.org/10.1016/j.scienta.2014.09.039

Li, T. and Q. Yang. 2015. Advantages of diffuse light for horticultural production and perspectives for further research. Front. Plant Sci. 6:1-5, https://doi.org/10.3389\%2Ffpls.2015.00704.

Liang, Z., Q. Zhang, K. Zheng, S. Zhao, P. Wang, J. Cheng, X. Zhang, and X. Chen. 2020. Effects of diffuse light on microclimate of solar greenhouse, and photosynthesis and yield of greenhouse-grown tomatoes. HortScience 55(10):1605-1613, https://dx.doi.org/10.21273/ HORTSCI15241-20.

Lin, A.C. and L. Huang. 1978. A study on photosynthesis of asparagus. Mem. Col. Agr. Natl. Taiwan Univ. 18(1):88-95, https://doi.org/ 10.2135/cropsci1999.0011183X003900040019x.

Liu, C.H., C. Ay, J.C. Kan, and M.T. Lee. 2018. The effect of radiative cooling on reducing the temperature of greenhouses. Materials (Basel) 11(7): 1166-1179, https://doi.org/10.3390/ma11071166.

Marcelis, L.F.M., A.G.M. Broekhuijsen, E. Meinen, E.M.F.M. Nijs, and M.G.M. Raaphorst. 2006. Quantification of the growth response of light quantity of greenhouse grown crops. Acta
Hort. 711:97-104, https://doi.org/10.17660/ ActaHortic.2006.711.9.

Moon, D.M. 1976. Yield potential of Asparagus officinalis L. Asparagus officinalis L. N. Z. J. Exp. Agr. 4:435-438, https://doi.org/10.1080/ 03015521.1976.10425913.

Mutwiwa, U.N., H.J. Tantau, S.I. Murunga, B. Elsner, and J.F.J. Max. 2017. Effects of a near infrared-reflecting greenhouse roof cover on microclimate and production of tomato in the tropics. CIGR. J. 19(3):70-79.

Nawalany, G., J. Radon, W. Bieda, and P. Sokolowski. 2017. Influence of selected factors on heat exchange with the ground in a greenhouse. Trans. ASABE 60:479-487, https://doi.org/ 10.13031/trans.11969.

Nichols, M.A. and D. Woolley. 1985. Growth studies with asparagus, p. 287-297. In: E.C. Lougheed, H. Tiessen (eds.). Proc. Sixth Inter. Asparagus Symp., Univ. Guelph, Guelph, Ontario, Canada.

Sarlikioti, V., P.H.B. de Visser, and L.F.M. Marcelis. 2011. Exploring the spatial distribution of light interception and photosynthesis of canopies by means of a functional-structural plant model. Ann. Bot. 107:875-883, https://doi.org/ $10.1093 \% 2$ Faob\%2Fmcr006.

Sarvajeet, S.G. and T. Narendra. 2010. Reactive oxygen species and antioxidant machinery in abiotic stress tolerance in crop plants. Plant Physiol. Biochem. 48:909-930, https://doi.org/ 10.1016/j.plaphy.2010.08.016.

Seginer, I. 1994. Transpirational cooling of a greenhouse crop with partial ground cover. Agr. For. Meteorol. 71:265-281, https://doi. org/10.1016/0168-1923(94)90015-9.

Shelton, D.R. and M.L. Lacy. 1980. Effect of harvest duration on yield and on depletion of storage carbohydrates in asparagus roots. J. Amer. Soc. Hort. Sci. 105:332-335.

Stanghellini, C. 1987. Transpiration of greenhouse crops: An aid to climate management. Univ. of Wageningen, The Netherlands, Ph.D. Diss.

Taiwan Central Weather Bureau. 2021. Agrometeorology. 20 May 2021. <https://www.cwb. gov.tw/V8/C/L/Agri/Agri_month.html>.

Wahid, A., S. Gelani, M. Ashraf, and M.R. Foolad. 2007. Heat tolerance in plants: An overview. Environ. Exp. Bot. 61:199-223, https://doi.org/ 10.1016/j.envexpbot.2007.05.011.

Wang, C.S. 1970. Studies on "mother stalk method" of asparagus harvesting. J. Chinese Soc. Hort. Sci. 16(2):16-23, https://doi.org/10.6964\% 2fJCSHS.197003.0016.

Wolyn, D.J. 1993. Estimates of marketable yield in asparagus using fer vigor index and minimum number of daily harvest records. J. Amer. Soc. Hort. Sci. 118:558-561, https://doi.org/ 10.21273/JASHS.118.5.558.

Woolley, D.J., S. Sudjatmiko, Y.F. Yen, K.J. Fisher, and M.A. Nichols. 1996. Carbon dioxide exchange characteristics and relative growth rates of two asparagus cultivars on relation to temperature. Acta Hort. 415:201-207, https:// doi.org/10.17660/ActaHortic.1996.415.29.

Yen, Y.F., M.A. Nichols, and D.J. Woolley. 1996. Growth as asparagus spears and ferns at high temperatures. Acta Hort. 415:163-174, https:// doi.org/10.17660/ActaHortic.1996.415.24.

Yue, D., Y. Desjardins, M. Lamarre, and A. Gosselin. 1992. Photosynthesis and transportation in vitro culture asparagus plantlets. Scientia Hort. 49:9-16. 